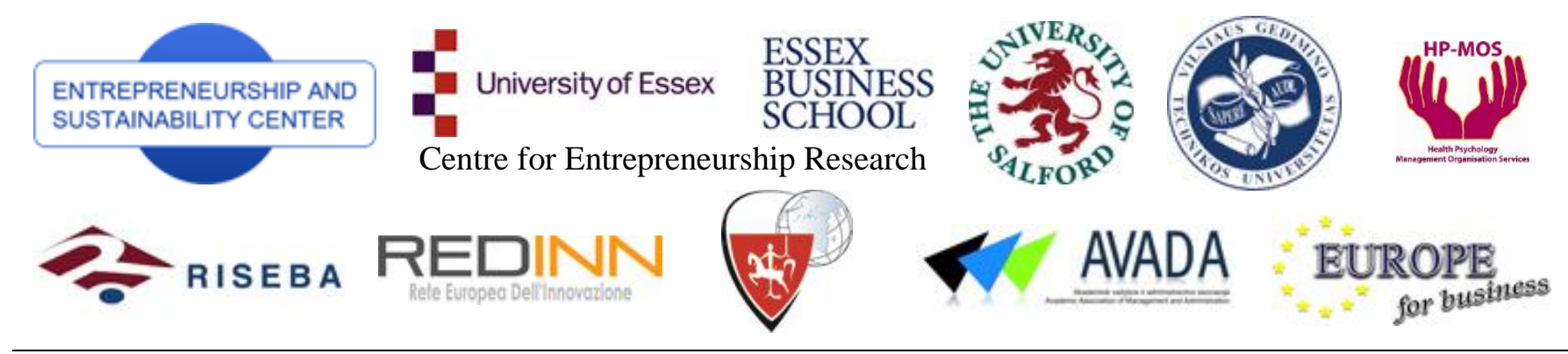

ENTREPRENEURSHIP AND SUSTAINABILITY ISSUES

ISSN 2345-0282 (online) http://jssidoi.org/jesi/aims-and-scope-of-research/

\title{
EVALUATION OF FRAUDS IN PUBLIC SECTOR
}

\author{
Lukas Giriūnas ${ }^{1}$, Jonas Mackevičius ${ }^{2}$ \\ ${ }^{1,2}$ Vilnius University, Saulètekio al. 9, LT-10222, Vilnius, Lithuania \\ E-mails: ${ }^{l}$ lukas.giriunas@ef.vu.lt; ${ }^{2}$ jonas.mackevicius@ef.vu.lt
}

Received 05 November 2013; accepted 16 January 2014

\begin{abstract}
Frauds greatly influence the performance of the enterprises and decisions made by users of accounting information. Therefore, fraud analysis is at high importance among the executives of state-owned enterprises and budgetary institutions. Probability of detecting a fraud is lower than finding errors, since fraudulent activities are deliberately hidden: they are usually pursued using complex and carefully planned schemes. The results of the empirical research have revealed that utmost importance in encouraging frauds can be attributed to the conditions where various individuals can commit frauds. Thorough analysis of scientific literature, accounting and audit regulations had allowed the authors to prepare the classification of principle conditions increasing fraud risk. This classification will aid public sector executives, accountants and auditors in detecting fraudulent activities, identifying their causes and location, objectively evaluating their effect on performance of the enterprise and foreseeing specific measures of prevention.
\end{abstract}

Keywords: Public sector, frauds, classification of frauds, evaluation, analysis of frauds.

Reference to this paper should be made as follows: Giriūnas, L.; Mackevičius, J. 2014. Evaluation of frauds in public sector, Entrepreneurship and Sustainability Issues 1(3): 143-150.

DOI: http://dx.doi.org/10.9770/jesi.2014.1.3(3)

JEL Classifications: K40, M42, M48

\section{Introduction}

Changes originating from currently pursued public sector's accounting reform in Lithuania have determined the changing accounting policy in state-owned enterprises and budgetary institutions, due to this reason likelihood of frauds increases. Frauds not only distort enterprise's financial reports, but also can mislead internal information users, who based on misleading financial reporting can make unsuitable strategic or managerial decisions, forecasts and perspectives, and their unsuitable selection and management can in turn reduce enterprise's competitiveness. Frauds can also create extensive threats to external information users, since from the first glance minor fraudulent activity and its misleading financial information can cause losses for banks, investors, buyers and suppliers. Nevertheless, a rather large harm can be caused to the State as well, since document forging is often used not only to mask frauds but also to avoid taxes. The research object is the evaluation of frauds in Lithuania's public sector enterprises. The research aim is to classify and evaluate frauds committed in public sector's enterprises and budgetary institutions. The following objectives have been raised in order to achieve the above mentioned aim:

- To analyze the effects and specifics of frauds in public sector;

- To perform a classification analysis of frauds existing in public sector. 
The authors of the article have analyzed the scientific literature, empirical studies and economic literature, used synthesis, information collection, comparison, specification and generalization methods together with practical study in respect to assessment of fraud expression in public sector.

\section{Analysis of frauds specifics in public sector}

Frauds are one of the most harmful social phenomena, which originated in ancient times and still persist. Fraudulent activities did not diminish in the age of democracy, high-technology and information systems, rather new types of frauds, and new ways of covering them up, emerged. Changes originating from recently pursued public sector's accounting reform have caused accounting policy to change in state-owned enterprises and budgetary institutions, due to this reason likelihood of frauds increased. According to performed statistical data analysis, the largest percentage of frauds committed can still be attributed to public, rather than private sector (see Figure 1).

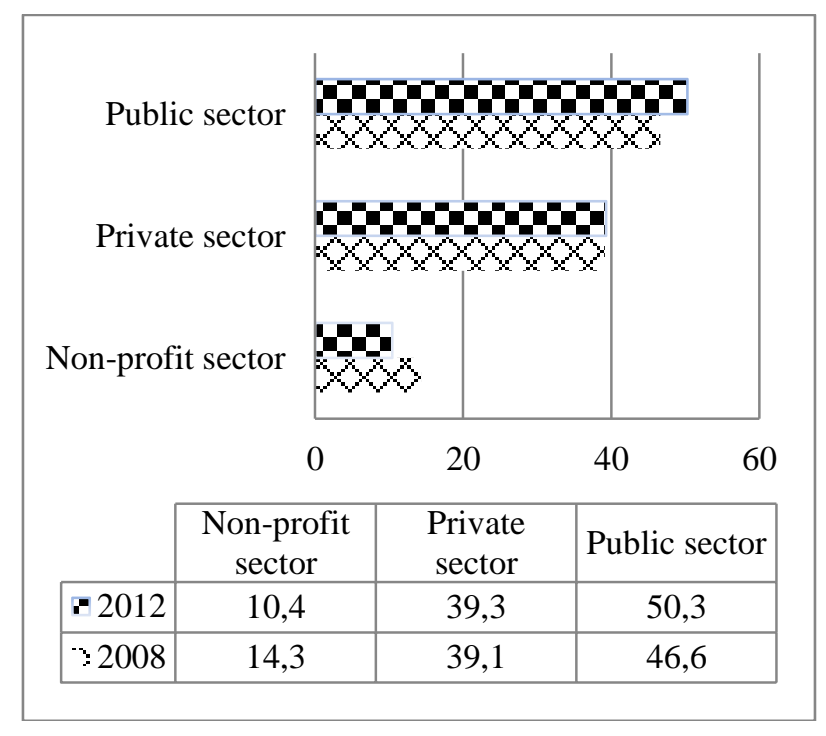

Fig.1. Frauds by sector, in percentage, 2008-2012

Source: prepared by authors based on ACFE data (2008-2012)

From the figure above we can see that the percentage of frauds committed in public sector is much greater than in private sector. This can be explained by the fact that weaker internal control in public sector creates possibilities for larger number of frauds to be committed. Besides, audits are carried out regularly in private sector as opposed to public sector. Therefore, based on frauds' triangle or quadrilateral components we can claim that more frauds are committed in public sector due to favorable conditions. Based on the performed scientific literature analysis (Pranka 2012; Kim 2012; Black and Park 2012; Mackevičius and Kazlauskiene 2009), we can conclude that frauds happen while reflecting various accounting operations. According to Doig and Levi (2009), main distortions of financial information happen due to incorrect interpretation of economic operations or conscious distortions, which are the most harmful and public sector enterprises suffer most material harm from. This statement is also confirmed by the statistical data analysis (see Figure 2). From the figure 2 we can see the overall harm caused by frauds is greater in private sector than in public. Based on the statistical data analysis we can state, that despite the fact that more frauds are committed in public sector, greater harm is caused in private sector. Harm caused by frauds is usually not limited to one particular enterprise, but often it is also transmitted to all related entities - investors, suppliers, banks, insurance companies. Even though greatest attention in the scientific literature is given to frauds committed in the private sector, most modern and innovative frauds are more often committed in public sector, since one executive and one or a few employees as an organized crime unit is sufficient for this type of fraud. 


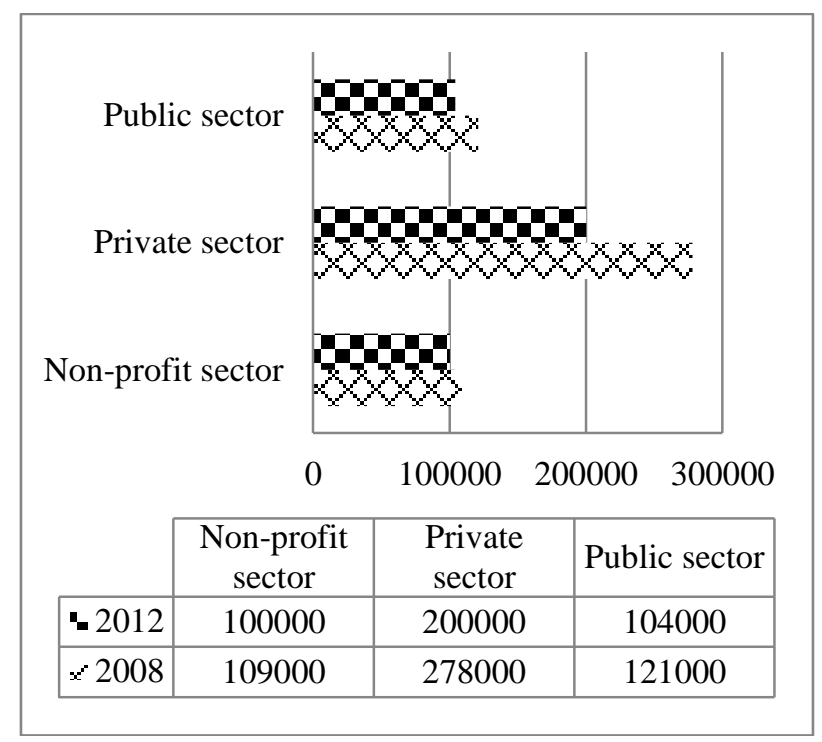

Fig.2. Average scope of losses subjective to frauds, in USD

Source: prepared by authors based on ACFE data (2008-2012)

According to Asare (2009) and Jones (1993), perpetrators of fraud in public sector often possess high motivation to commit it, have sufficient abilities and confidence. Frauds committed in public sector are usually more profitable than in private sector and the risk that it will be uncovered is much lower (Gee $e t a l$. 2010).

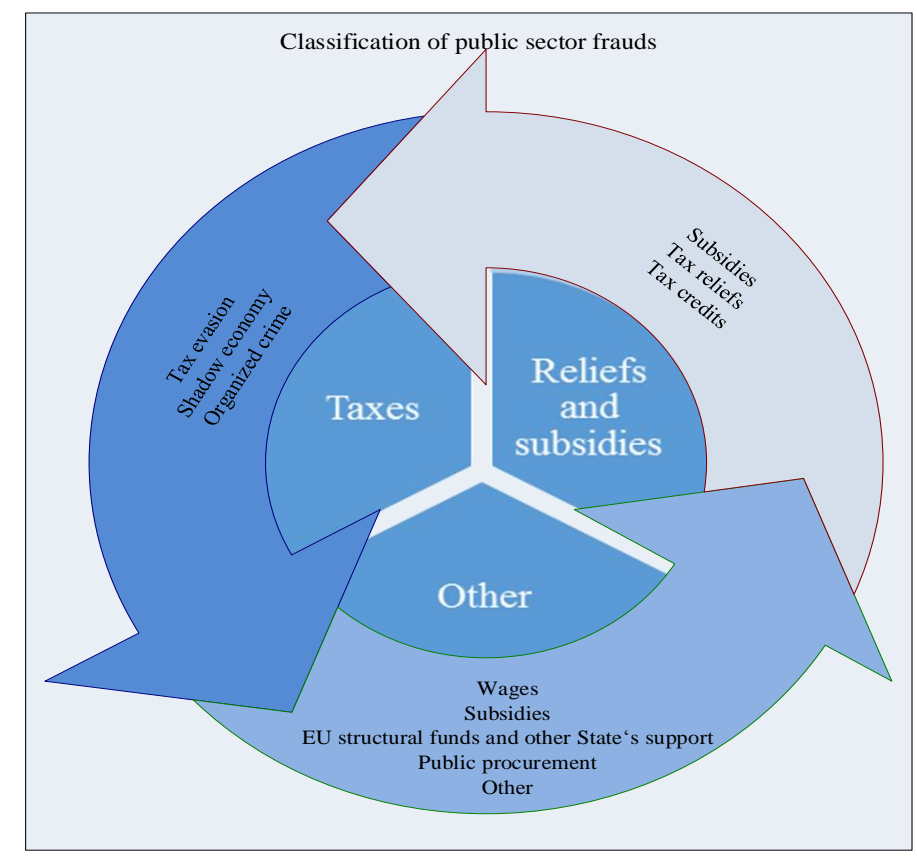

Fig.3. Structuration of frauds in public sector

Source: prepared by authors based on Hemmerechts et al. (2011); Brooks et al. (2009); Burgess et al. 2012.

Therefore, the interest of individuals ready to commit frauds is greater. Thus, we can conclude that different types of frauds exist in private and public sectors and they are influenced by different external factors (see Figure 3). Public sector is very attractive to perpetrators of fraud, who take advantage of tax system, reliefs and subsidies for personal enrichment. According to Gannon and Doig 2010, all institutions and public sector enterprises are subjects in valuating fraud risk, since fraud can be committed in daily operations, for instance, 
calculating wages, carrying out public procurements, etc. As seen from practice, frauds committed in budgetary institutions are often uncovered when tax administrators quantitatively evaluate direct and indirect tax collection and discover a gap between planned and collected taxes. According to Mackevičius (2012), frauds in state-owned enterprises are often uncovered only during State audits or other checks caused by unforeseen circumstances. Nevertheless, even then they are hard to uncover, since they are planned carefully and in advance, and their effects are well hidden or destroyed. Therefore, it is essential to classify public sector frauds.

\section{Classification frauds in public sector}

Term fraud has a broad meaning, which must be defined before classifying public sector frauds. It can encompass various criminal actions:

- Organized fraud - such as VAT frauds "carousel", "boiler room fraud", stock manipulation, internal trade fraud, collateral fraud, payment card frauds;

- Frauds against several individuals - such as "Ponzi" scheme;

- Individual frauds - such as misappropriation of assets, which does not fulfill the criteria for organized crime, but is usually performed in a rather organized manner.

Practice shows that there are various types of frauds. Often at the first glance innocent-looking errors can be well-organized and involve organized crime, which in turn can have effects on private and public sectors. Therefore, it is imperative to classify public sector frauds (see Figure 4).

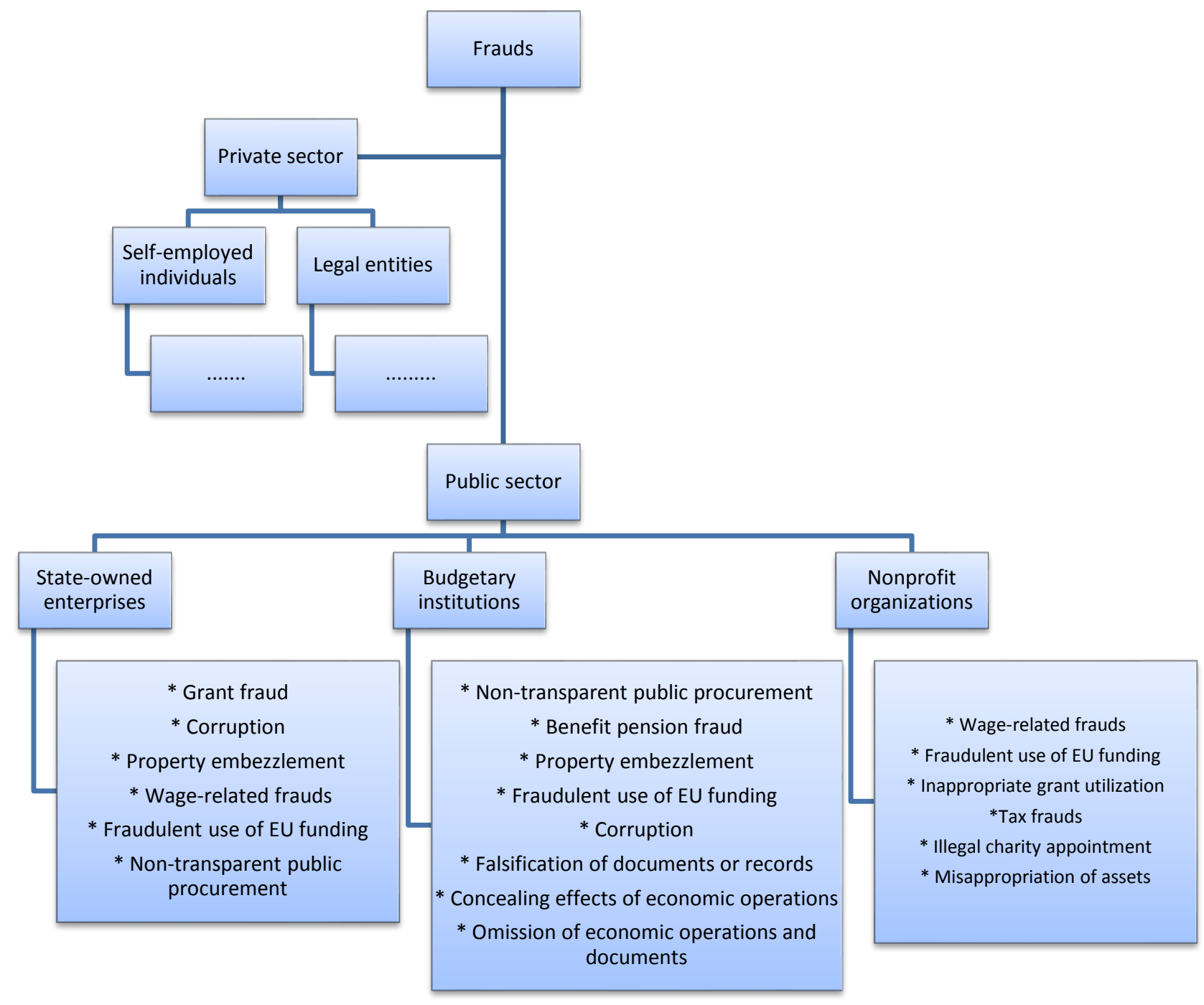

Fig.4. Classification of public sector frauds 
Public sector frauds should be categorized based on their manifestation areas, since depending on their nature some of them might appear only in state-owned enterprises, whereas the others only in budgetary institutions. According to Brooks (2012), the oldest fraud in practice is misappropriation of assets, the development of which started from cash theft to stock theft. Majority of such frauds in state-owned enterprises are carried out using various fixed or current asset acquisition, production and recovery operations. Most common fixed asset frauds in the public sector, or to be more precise in state-owned enterprises, are:

- Repair or reconstruction of assets is undertaken and part of the funds allocated for it is misappropriated in the form of goods or services allocated for reconstruction;

- Asset value is not corrected, even though its book value differs from real value and sold to predefined individuals for a lower than market price;

- Asset is sold to predefined individuals for the residual value, which does not correspond to real market value of the asset;

- Purchased fixed assets are attributed to current assets, calculated as part of cost and later written off as unsuitable for use, and misappropriated by predetermined individuals.

State-owned enterprises, as all other organizations, are subjects for fraud risk. Daily operations can involve wage-related and public procurement frauds while purchasing goods and services. Therefore, we can conclude that fraud manifestation can be of an extremely broad spectrum. The following types of frauds are rapidly developing: revenues obtained from current assets written off as unsuitable for use and misappropriated by predetermined individuals; concealment of revenues obtained from leased assets; manipulations of tangible fixed assets' write offs; misappropriation for assets for personal use, etc. Besides the listed types of frauds, corruption is rather common in public sector, which according to Tambulasi (2009), is perceived as unlawful gain through professional duties (official position) and position in the society. Recently corruption extended from state-owned enterprises to budgetary institutions, where bribery, public procurement conflicts and extortions are wide spread. Nevertheless, most of the abuses of the official position occur during the organization of public procurements and auctions (Dwiputrianti and Lan 2011). Public sector is very attractive to perpetrators of fraud who abuse taxation system, reliefs and subsidies' systems for personal gain.

Frauds greatly influence business continuity and financial performance. Therefore, it is imperative to create a fraud prevention system. Great role here is played by auditing. Auditors performing fraud auditing firstly have to determine and evaluate what is the weakness of internal control system, enterprise's internal and external environment, history of uncovered frauds, illegal transactions made and who could have authorized them, perform analysis of complains, etc. When facing fraud, main steps of auditors, according to Mackevičius and Kazlauskienè (2009), should be these:

- Perform audit, in order to obtain valid proof of fraud;

- Expand the scope of audit;

- Determine whether fraud was significant;

- Determine how and why fraud took place;

- Keep proper professional caution in order to keep further investigation uncompromised;

- Announce the information about fraud (if allowed by law).

Depending on legal entities operating in public sector, organization of audit and fraud prevention process can differ from private sector (see Figure 5). It is difficult to foresee changes and crisis situations; therefore, it is important to apply various prevention measures that would determine the weaknesses of the entity and find conditions, which increase the likelihood of fraud. The executives of enterprises or budgetary institutions should define what managerial levels or departments are responsible for certain frauds or illegal actions. They should strive to direct attention of internal and external auditors towards fraud audit. It is proven that yearly audited entities with strong internal auditing have a much lower fraud risk. 


\section{IDENTIFICA TION}

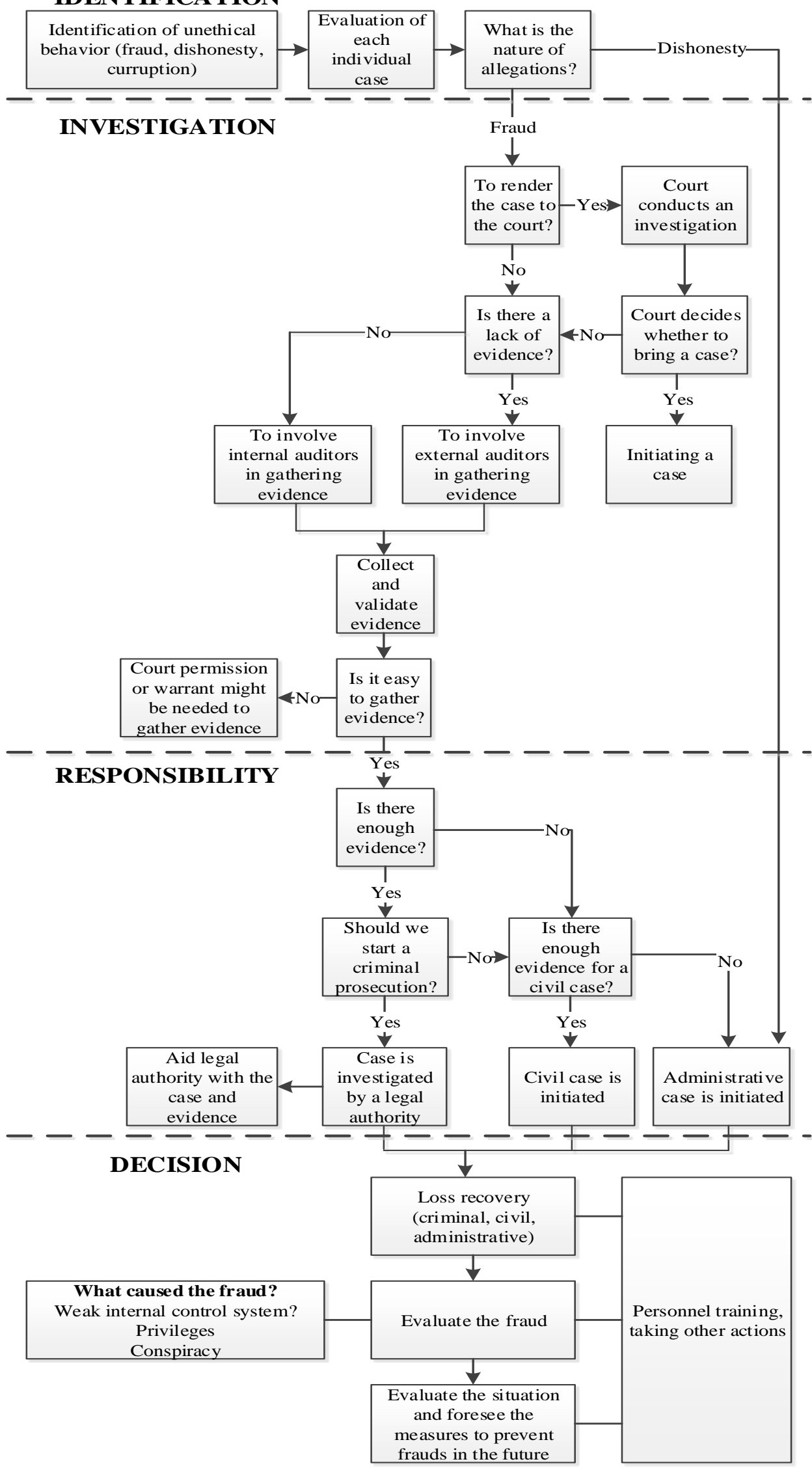

Fig.5. Fraud detection and prevention process

Source: prepared by authors based on Button et al. (2009); Magrane and Malthus (2010) 
Therefore, auditors should first determine and evaluate: the weakness in internal control system; the internal and external environment of the entity and factors influencing it; previous uncovered frauds; possible deviations from regulated accounting system in the economic branch or entity; possible illegal transactions and who could authorize them; management techniques and measures used by the institution's management.

\section{Concluding remarks}

The performed statistical data analysis shows that, besides the fact that the overall losses caused by frauds in the public sector are lower than in the private sector, they are much more frequent. It is important to stress, that frauds are most often initiated by upper level management. They are carefully planned, committed consciously, so that they would be hard to track. Therefore, it is much harder to identify them than errors. In order to identify and eliminate public sector frauds it is necessary to explore and evaluate managerial techniques, control systems, to determine their suitability, effectiveness and whether they might encourage frauds. Nevertheless, it is also imperative to distinguish between different public sector frauds based on the area where they might occur, since certain types of frauds can be committed only in state-owned enterprises, others only in budgetary institutions. This in particular has an effect on organization of audit and identification of fraud prevention measures.

\section{References}

Asare, T. 2009. Internal Auditing in the Public Sector: Promoting Good Governance and Performance Improvement, International Journal on Governmental Financial Management 9(1): 15-28.

Black, D. A.; Park, K. 2012. Some Problems with Place-Based Crime Policies, Criminology \& Public Policy 11(2): 327-334. DOI: DOI: http://dx.doi.org/10.1111/j.1745-9133.2012.00811.x

Brooks, G.; Button, M.; Frimpong, K. 2009. Policing fraud in the private sector: a survey of the FTSE 100 companies in the UK, International Journal of Police Science and Management 11(4): 493-504.

Brooks, G. 2012. Fraud and corruption: measurement, strategies and policing. Doctoral dissertation, University of Portsmouth.

Burgess, S.; Propper, C.; Ratto, M.; Tominey, E. 2012. Incentives in the public sector: evidence from a government agency. Available on the Internet: < http://workspace.unpan.org/sites/internet/documents/UNPANCGG02606137.pdf>.

Button, M.; Gee, J.; Brooks, G. 2011. Measuring the cost of fraud: an opportunity for the new competitive advantage, Journal of Financial Crime 19(1): 65-75.

Doig, A. 1995. Mixed signals? Public sector change and the proper conduct of public business, Public Administration 73(2): 191212 .

Doig, A.; Levi, M. 2009. Inter-agency work and the UK public sector investigation of fraud, 1996-2006: joined-up rhetoric and disjointed reality, Policing \& Society 19(3): 199-215.

Dwiputrianti, S.; Lan, S. 2011. Scope of auditing on the quality of content in the Indonesian external public sector auditing reports, International Review of Public Administration 16(3): 133-149.

Gannon, R.; Doig, A. 2010. Ducking the answer? Fraud strategies and police resources, Policing \& Society 20(1): 39-60.

Gee, J.; Button, M.; Brooks, G. 2010. The financial cost of UK public sector fraud: a less painful way to reduce public expenditure. Milton Keynes: MacIntyre Hudson

Giriūnas, L. 2009. Imonès apskaitos kontrolinių funkcijų optimizavimas [Evaluation of condition of internal control system in the company], Ekonomika ir vadyba: aktualijos ir perspektyvos [Economics and management: current issues and perspectives] 1(14): $103-113$.

Hemmerechts, K.; Verhage, A.; Cools, M. 2011. Bringing the private into the public: reporting private sector fraud in Belgium, $E U$ Criminal Justice, Financial \& Economic Crime: New Perspectives 5: 185-204.

Jones, P. 1993. Combating fraud and corruption in the public sector. Chapman \& Hall.

Kemp, G. 2010. Fighting public sector fraud in the 21st century, Computer Fraud \& Security (11): 16-18.

Kim, Y. 2012. Simulating a Fraud Mechanism in Public Service Delivery, in A. Desai (Ed.). Simulations for Policy Inquiry. New York: Springer, 121-138. 
Magrane, J.; Malthus, S. 2010. Audit committee effectiveness: a public sector case study, Managerial Auditing Journal 25(5): $427-$ 443.

Mackevičius, J. 2012. The Cycle of Frauds and Conditions Increasing Their Risk, Business: theory and practice 13(1): 50-56.

Mackevičius, J.; Kazlauskienė, L. 2009. The fraud tree and its investigation in audit, Ekonomika [Economics] 85: 90-101.

Michael, K. 2011. Fraud prevention and control in the public sector. IIR Conferences: An Informa Business. Sydney, Australia.

Pranka, D. 2012. Apgaulès samprata ir reikšmė atribojant sukčiavimą ir civilinès teisès pažeidimą [The definition of deception and its influence in marking the line between fraud and tort], Socialiniu mokslu studijos [Societal studies] 4(2): 663-683.

Tambulasi, R. I. 2009. The public sector corruption and organized crime nexus: The case of the fertilizer subsidy programme in Malawi, African Security Studies 18(4): 19-31.

Lukas GIRIŪNAS, doctor of social sciences in economics, lecturer. Research interests: accounting, finance analysis, audit, internal control.

Jonas MACKEVIČIUS, habil doctor of social sciences in economics, Professor, Emeritus. Research interests: accounting, international accounting, finance analysis, audit. 